Mukaddime, 2019, 10(1), 37-52

DOI: 10.19059/mukaddime.514095

\title{
XIX. Yüzyıl Sonlarında Cizre'de Kolera Salgını ve Yol Açtığı
} Tahribat

\section{Bilal Altan}

Öz: Tarihsel süreç içerisinde insanları korku ve endişeye sevk eden salgın hastalıklar yaşanmıştır. Meydana geldiği toplumda etki derecesine göre az ya da çok felakete yol açabilen salgın hastalıklardan biri hiç şüphesiz koleradır. Esas olarak Cizre'de 1890 yılı yazında zuhur eden kolera vakası incelenmekle birlikte, mezkûr tarihten önce de yer yer kolera vakalarının yaşandığı bilinmektedir. 1836, 1848, 1850, 1865-1866 yıllarındaki kolera vakaları verilebilecek örneklerdir. Musul kaynaklı 1890 kolera vakası, Cizre'yi de etkisi altına almış, çok sayıda insanın vefatına yol açmıştır. Bu çalışmada, Osmanlı Devleti'nde birçok vilayette görülen 1890 yılı kolera vakasının Cizre özelinde yol açtığı özellikle musap ve ölüm vakalarının yanı sıra, koleraya karşı alınan tedbirlerin neler olduğunu belirlemek amaçlanmaktadır.

Anahtar Kelimeler: Cizre, Kolera, Salgın Hastalık, Karantina.

\section{The Cholera Outbreak at the End of 19th Century Cizre and its Devastating Impacts}

\begin{abstract}
In the historical process, several epidemics leading to fear and anxiety have been experienced. One of the epidemics that may lead to major or minor disasters in a society based on the degree of its impact is undoubtedly cholera. Although this study basically deals with the cholera case occurred in Cizre in the summer of 1890 , it is known that some other cases of cholera had happened before the date mentioned in 1836, 1848, 1850, 1865 and 1866. Originated in Mosul, the cholera case occurred in 1890 also affected Cizre, resulting in the death of a lot of people. This study aims to reveal the sufferers and deaths caused by the cholera case in 1890 in several provinces of the Ottoman Empire along with the precautions taken against it, particularly in the case of Cizre.

Keywords: Cizre, Cholera, Epidemic, Quarantine
\end{abstract}

${ }^{1}$ Dr. Öğr. Üyesi, Şırnak Üniversitesi, altanbil@gmail.com, Orcid: https://orcid.org/0000-0002-0194-3516

Makale Gönderilme Tarihi: 17.01.2019, Kabul Tarihi: 27.03.2019 


\section{Giriş}

Osmanlı arşiv belgelerinde illet-i kolera, illet-i âdiyye, illet-i mahûf, iștidâd-ı illet-i müdhişe gibi isimler verilen kolera, basit ifadeyle hijyen ile ilgili bir hastalık olup, erken tedavi edilmezse ölüme sebebiyet vermektedir. Hastalık, mikrobun mideden geçerek bağırsaklara yerleșip çoğalmasından meydana gelir. Hem salgın hastalık denilen edipemi hem de çok geniş bir alanda pek çok kişiyi yakalayan kıtalararası salgın denilen pandemi halini alabilen koleradan korunmada en önemli etken kişisel hijyendir. Epidemilerin görüldüğü vakitler sıcak aylardır ${ }^{2}$ (Gül, 2009: 241; BOA, MKT. MHM. 359-26; 346-83; Ayar, 2007: 4-5).

Korku kaynağı oluşturan, yoğun bir şekilde insan ölümlerine yol açan hususlardan biri, tarih boyunca meydana gelen veba, kolera, tifüs, tifo, çiçek ve grip gibi çeşitli salgın hastalıklardır (Sarıyıldız, 1994: 329). Bunlardan kolera, XIX. yüzyılın adı ölümle birlikte anılan karakteristik salgın hastalığı kabul edilmiştir (Ayar, 2007: 455). Kolera hastalığı daha ziyade Hindistan kanalı ile diğer bölgelere yayılmıştır (Sarıyıldız, 1996: 1). Hindistan'da Aşağı Bengal Deltası üzerinde bulunan Ganj ve Brahmaputra nehirleri arasındaki arazide lokal halde her vakit mevcut olan koleranın dünya nazarında önem kazanması, bu bölgeden önce yakın çevresine ve hemen sonra da tüm dünyaya yayılmaya başladığı 1817 yılından sonra gerçekleşmiştir. Nitekim, 1817-1823, 1829-1837, 1852-1862, 1863-1875, 18811896 ve 1899-1923 yıllarında kıtalar arası kolera salgınları yaşanmıştır (Ayar, 2007: 348).

Ticaret maksadı ile yapılan seyahatler, askeri sevkiyatlar, göçler ve hac gibi dinsel toplantılar kolaylıkla hastalıkların bir bölgeden diğerine yayılmasını kolaylaştırmaktaydı (Yılmaz, 2017: 29-31). İnsanların hayat tarzlarının sebep olduğu sağlıksız ortamlar, ekolojik dengenin bozulması, kıtlıklar, doğal afetler ve daha birçok sebep sonucunda salgın hastalıklar zuhur etmiş ve tedavi usulleri bulununcaya kadar toplu ölüm hadiselerine yol açarak insanlık tarihinde önemli bir rol oynamıştır (Kılıç, 2004: 11). Toprakları geniş bir alanı kaplayan Osmanlı Devleti'nin de kolera salgınlarından korunması zordu. XIX. yüzyılda, eski ticaret yollarının kesişme noktasında bulunan Osmanlı topraklarında bu hastalık, demografik, sosyal, psikolojik ve ekonomik alanlarda büyük çaplı zayiatlara sebep olmuştur (Ayar, 2007: 22). İlk defa 1817 yılında Aşağı Bengal'de dikkat çekmeye başlayan kolera, 1822'de Basra ve Bağdat üzerinden Anadolu ve Akdeniz sahillerine ulaşarak Osmanlı topraklarında görülmeye başlamıştır (Sarıyıldız, 2000: 310). Anlaşıldığı kadarıyla Osmanlı Devleti'nde hiçbir vilayet kolera salgınlarından kurtulamamıştır. Hastalığın yayılma alanlarına bakıldığında şehirler veya vilayetler coğrafi konumları itibariyle Osmanlı topraklarının farklı bölgelerinde bulunmaktadır (Gül, 2009: 244).

Koleraya karşı birtakım tedbirlere başvurulmuştur. Bunlardan biri, insan veya diğer canlıların bulaşıcı hastalıklarla karşılaşmış olabileceğinden hareketle,

\footnotetext{
Bilgiyi doğrulayıcı şekilde, Cizre örneğinde görüleceği üzere 1890 yılı kolera salgını yaz mevsimine denk gelmiştir.
} 
hastalık taşımadıkları kesinleşene kadar belli bir yerde alıkonulması demek olan karantinadır. Yine karantina, bazı hastalıkların bulaşıcı olduklarının tespitinden sonra, bu tip hastalıkların kontrol altına alınabilmesi için başvurulan bir yöntemdir. Avrupa ülkelerinde XV. yüzyıldan itibaren bir çare olarak başvurulan karantina yöntemine Osmanlı Devleti'nde XIX. yüzyılın ilk çeyreğinden sonra 1831 yılında geçilmiştir. Karantina yöntemine başvurulmasıyla hastalığın çıktığı bölgede kontrol altına alınması sağlanıyor; diğer şehir, bölge ve ülkelere yayılmasının önüne geçilmiş olunuyordu (Akyıldız, 1993: 265; Sarıyıldız, 1994: 332).

Osmanlı Devleti'nde karantina yeri için tahaffuz-hâne tabiri kullanılmıştır. Arapça sakınmak, korunmak demek olan tahaffuz kelimesinden gelen tahaffuzhâne bulaşıcı hastalıkların zuhurunda, karantinada bulundurulacak hastaların belirli müddeti geçirmek için ikametlerine tahsis olunan yerlere verilen addır (Pakalın,1993: 373). Geniş anlamda bir şehre salgın hastalığın bulaşmasını veya buradan başka yerlere sirayetini engellemek üzere, şehre giriş ve çıkış yapacakların sağlık durumlarının belli bir süre gözetim altına alındığı; bu gözetim sırasında yapılan muayenelerle şüphe çekici durumu saptananların sağlıklılardan ayrılması için alıkonulup tedavi edilmeye çalışıldığı yerlerdir (Develioğlu, 2008, 1016; Ayar, 2007: 378). Tahaffuz-hânelerde yapılan uygulamaya göre dışarıdan gelenler önce tıbbi muayeneye tabi tutulmuş, sonra eşya ve malları dezenfekte edilerek gerekli temizlik işlemlerinden geçirilmişlerdir (Dağlar, 2007: 372). Şehirlerde kurulan tahaffuz-hânelerin yanı sıra, kaza ve nahiyelere varıncaya kadar gerekli önemli kavşaklarda karantinahaneler mevcuttur (Gül, 2009: 248249).

Salgın baş gösterdiğinde on beş günde bir ölenlerin kimlik bilgileri ile ölüm sebeplerinin yer aldığı tabloyu merkeze göndermek ve bölgenin genel sağlık durumu hakkında rapor sunmak karantina hekimlerinin görev alanındaydı. Hastalık durumunda gerekli uyarıları yapıp, bulunduğu yerdeki yabancı sefaret görevlileri yanında halk sağlığı ile ilgilenen devlet görevlilerine bilgi vermek, kendi bölgesinde çıkacak bir salgın hastalık durumunda tüm gerekli tedbirleri almak da karantina hekimlerince gerçekleştirilmiştir (Yıldırım, 2006: 20).

Diğer bir tedbir karantina usulünün dar kapsamlı başka bir versiyonu olan kordon uygulamasıydı. Kordonda asıl olan hastalığın zuhur ettiği yerden dışarı yayılmasını engellemek ve aynı yerde imha edilmesini sağlamaktı. Kordon uygulamalarında süre oldukça önemli olup genellikle salgının şiddetine göre yetkililerce kararlaştırılmıştır (Ayar, 2007: 323; Arslan, 2015: 76).

Osmanlı Devlet makamları kolera karşısında gerekli sosyal duyarlılığı göstermiştir. Kordon altına alınan yerlerde bulunan ahalinin her türlü ihtiyaçları devlet tarafından karşılanırken yevmiye usulüyle çalışan fakir fukaranın kordondan çıkamamalarından dolayı doğan zararları bile tazmin edilmiştir. Aynı şekilde tahaffuz-hânelerde bekleyen fakir fukaranın da karnı doyurulmuş, gidecekleri yerlere ücretsiz taşınmaları sağlanmıştır (Ayar, 2007; 211-212). Ancak 
sosyal duyarlılığa karşın, koleranın yol açtığı yıkımı önlemede çoğu zaman istenilen neticeler alınamamaktaydı. Bunda yeterli sayıda yetişmiş hekim bulunmaması, bu illetin ne ahali ne de yerel idareci ve tabipler tarafından yeterince tanınmaması, Osmanlı toplumunun kaderciliği, halkın çoğunluğunun kişisel hijyene değer vermemesi, Osmanlı Devleti'nin o yıllarda bir mali darboğazda bulunması, altyapı hizmetlerinin eksikliği, görevli tayinlerinin yapılamaması, alet ve edevat eksikliğinin tamamlanamaması, hastalığın zuhur ettiği yerden veya şehirden dışarı çıkmaması için oluşturulması gereken kordonlarda vazife yapanların bir türlü yeterli sayıya ulaştırılamaması başlıca etkenlerdi (Ayar, 2007; 456). Devletin müdahale yöntemi ve halkın tutumu koleranın görüldüğü alanlarla süresinin farklılaşabilmesine veya değişebilmesine etki etmekteydi (Yıldız, 2014: 38).

Hastalıklar demografik yapıya zarar vermekte, tarım ile uğraşan ahaliyi etkilemekte ve zahire üretiminde düşüşe sebep olabilmekteydi. Bunların yanı sıra salgın hastalıkları engellemek maksadıyla oluşturulan karantina bölgeleri, menfaati çok fazla olmasına rağmen, tarım ve ticareti zaman zaman sekteye uğratmaktaydı (Asan, 2018: 7).

\section{Cizre'de 1890 Yılı Öncesi Salgın Hastalıklar}

Cizre, Dicle Nehri kenarında, sur içinde yer alan ve işlek yollar üzerinde bulunan eski bir yerleşimdir. Eski bir yerleşim merkezi hüviyetiyle Cizre farklı zaman dilimlerinde veba, kolera, sel, deprem gibi doğal ya da sosyal bazı felaketlere maruz kalmıştır. Cizre gibi ilkel ortamlarda felaketlerle birlikte sarî hastalıkların yayılması ve zararlar vermesi kaçınılmaz olmuştur (Tüzün, 2014: 534).

XIV. yüzyılın başlarında diğer bir deyişle Hicri 718/1318 dolaylarında Cizre'de vebanın yol açtığı ölümler gerçekleşmiştir (Makrîzî, 1971: 180). Cizre, Akkoyunlu Devleti hükümdarı Uzun Hasan döneminin ilk yıllarında da veba salgınına uğramış ve salgın şehirde toplumsal bir felakete yol açmıștır. Hicri 860/1455-1456 yılına denk gelen felaket neticesinde çok sayıda insan hayatını kaybetmiştir (Gandur, 1990: 192).

1800'de coğrafi bir terim olarak bir hilali andırdığı belirtilen, pek çok veba salgınının çıkış noktası olarak görülen Kürdistan'ın sınırları dâhilinde bulunan şehirlerden özellikle Süleymaniye ve Mardin dışında Cizre'de de vebanın varlığına dikkat çekilmektedir. 1830'da ise Kürdistan'ın güney eteğinde bulunan Süleymaniye, Kerkük, Musul ve Dicle üzerindeki Cizre gibi şehirlerde veba hastalığı çıkmıştır (Panzac, 1997: 44). 1836 yılı itibariyle Cizre'de hem veba hem de kolera gibi salgın hastalıklar olduğu anlaşılmaktadır. Şöyle ki 1836 yılında Reşit Paşa tarafından düzenlenen harekâtla Cizre ve Botan ele geçirilmiştir. Bu süreçte savaş dışında veba ve kolera şehri harabeye çevirmiş; oldukça sakin bir hal alan Cizre'de açlık sıkıntısı da baş göstermiştir (Shiel, 1838: 67-87). 
Diyarbakır'ın dâhil olduğu Anadolu'nun güneydoğusunda yer alan vilayetlerde yüzyıl boyunca kolera etkili olmuştur. Özcoşar, Cizre'nin de dâhil olduğu Mardin ve çevresi için 1848 yılında Cizre Mirliği'nin başı Bedirhan Bey'in isyanının hemen sonrasında XIX. yüzyıldaki ilk kolera salgınının zuhur ettiğini belirtmektedir ${ }^{3}$. Salgın dolayısıyla birçok kişi yerlerini terk etmek zorunda kalmış; ancak alınan tedbirlerle hastalık kısa sürede ortadan kalkmıștır. Anadolu Ordû-yi Hümâyûn Reisi Muammer Paşa'nın sadrazama göndermiş olduğu tahriratta, konuyla ilgili gelişmeler rapor edilmiştir. Muammer Paşa, Cizre'de zuhur eden hastalığın on dört gün sürdüğünü ve ardından kalktığını bildirmiştir (Yıldız, 2014: s. 40; Özcoşar, 2006: 795). 1850 yılında da Musul, Diyarbakır ve Cizre taraflarında kolera hastalığı zuhur etmiștir. Hatta koleradan dolayı Bağdat'a gönderilmiş olan Fransalı Tabip Deroz, Bağdat'tan dönerken mezkûr mahallerin memurları tarafından hastalıklı ahaliye bakmaları için alıkonulmuştur (BOA, A. AMD. 20/50).

Dolapönü'nün Süryani Tabip İshak’a dayandırdığı aktarımına göre 1865 yılının Ocak ayından Kasım ayına kadar süren bir kolera salgını Mardin’i kasıp kavurmuş ve 975 kişinin vefatına sebep olmuştur (Dolapönü, 1972: 97). Aynı kolera salgını 1865 yılında Kürdistan Vilayeti dâhilindeki Cizre'de de zuhur etmiş ve 1866 yılı ortalarına kadar devam etmiştir. Şiddetini arttırdığı belirtilen kolera dolayısıyla Cizre'ye tabip gönderilmiştir. Tabip gözetiminde zuhur eden koleranın sirayetinin önlenebilmesi adına gerekli tedbirlere başvurulmuşsa da henüz istenen şekle girmediği bildirilmiştir (BOA, MKT. MHM. 346/83; 359/26). Esasında ölüm vakalarına da yol açan söz konusu kolera hastalığı Kürdistan Valiliğinden ilgili makamlara tifo hastalığı diye aktarılmıştır. Ancak sonradan hastalığın tifo değil, kolera olduğu tespit edilmiştir (BOA, MKT. MHM. 358/35).

1889 yılında Anadolu'nun bazı mahallerinde çiçek hastalığı zuhur etmiştir. Diyarbakır Vilayetinin merkeze bildirdiğine göre zuhur eden hastalıktan herhangi bir kayıp yaşanmamış ve hastalık atlatılmıştır. Siverek'ten başka diğer kimi mahallerde tabip, cerrah ve aşıcı bulunmadığından çocukların aşısız kaldığı, çiçek hastalığının ara sıra hüküm sürdüğünden vilayet teşkil eden üç sancak için birer daimi ve seyyar aşı memurları talep edilmiştir. Ayrıca Cizre Belediyesi varidatından karşılanmak üzere bir tabip tayininin lüzumuna yer verilmiştir (BOA, DH. MKT. 1678/50).

\section{Cizre'de 1890 Yılı Kolera Salgını}

1890 yılı kolera salgınının yaşandığı Cizre, mezkûr tarih itibariyle Diyarbakır Vilayetinin Mardin Sancağına bağlı bir kaza konumundadır (Diyarbakır Salnameleri, Cilt 4, 43-48). Diyarbakır Vilayeti ya da Mardin Sancağı merkezi ve çevresinde yaşanan salgınların ve bu doğrultuda alınan kararların Cizre'yi etkileme olasılığı bulunmaktaydı. XIX. yüzyıl içerisinde birçok yerde olduğu gibi Diyarbakır Vilayetinde de 1843, 1848, 1851, 1866 ve 1879 yıllarında kolera salgınları olmuş ve bir hayli can kaybına sebebiyet vermiştir (Bozan, 2015: 221).

\footnotetext{
3 Ancak Shiel'in 1836 yılında Cizre için sözünü ettiği koleranın ilk olma ihtimali daha yüksektir.
} 
1890 Nisan'ında Musul'da varlığı bilinen kolera, yaz başlarından itibaren kuzeye çıkarak Hakkâri, Erbil, Cizre, Mardin ve Diyarbakır'dan sonra Ağustos'ta güneyde Bağdat ve Basra'da hüküm sürmeye başlamıştır. Eylül'de Van, Halep, Urfa, Harran, Şam ve nihayet 1890 Ekim sonunda ise Erzincan ve diğer yönden Hama'ya kadar geniş bir alana yayılmıştır (Ayar, 2007: 35). Belirtildiği üzere 1890 yılında görülen ve Musul kaynaklı olan kolera, Cizre'ye de sirayet etmiş ve etkisini hissettirmiştir ${ }^{4}$ (BOA, DH. MKT. 1725/34). Ayrıca Cizre'deki salgın mahalli düzeyde kalmamış, kimi zaman hafif kimi zaman şiddetli seyrederek yaklaşık iki buçuk ay sürmüştür. Cizre'de koleranın şiddetini hissettirdiği ve musaplarla vefatların yoğun yaşandığı süreç, 26 Haziran 1890-11 Ağustos 1890 yılını kapsayan bir buçuk aylık zaman dilimidir. 11 Ağustos'tan itibaren koleranın def edildiği yapılan tahkikler neticesinde belirlenmiştir ${ }^{5}$ (BOA, DH. MKT. 1759/107).

Cizre'de koleranın zuhur etmesinden kısa bir süre sonra iki kişinin vefat etmesi üzerine Dördüncü Ordu-yi Hümâyûn'dan memuren gönderilen ve kazada bulunan Tabip Kolağası Mehmet Efendi tarafından durumla ilgili hazırlanan rapor Cizre Kaymakamlığınca Diyarbakır Vilayetine bildirilmiştir. Vilayet makamınca durum Dâhiliyye ve Sıhhiyye nezaretlerine intikal ettirilmiştir. İntikal ettirilen haber üzerine Halep'te bulunan Tabip Furado Diyarbakır'a gelmiş ve Cizre'de hastalığın zuhur eylemesi üzerine vilayetin genel sağlık durumunu tahkike başlamıştır. Tabip Furado tahkikat ile uğraşırken Cizre'de bulunan Asker Tabibi Mustafa Efendi ile Tabip Kolağası Mehmet Efendi'nin yaptıkları müracaatlardan Cizre'de koleranın zuhur eylediğinin anlaşılmasıyla Tabip Furado kaza mahalline gönderilmiş ve korunma tedbirleri için azami derecede itina gösterilmesi ilgililere tebliğ edilmiştir (BOA, Y. HUS. 236//60; BOA, DH. MKT. 1737-62; BOA, Y. PRK. TKM. /18/15).

Tabip Furado Cizre'ye geldikten sonra kolera hastalığı hakkında incelemeler yapmıştır. 6 Temmuz 1890 yılında Sıhhiyye Nezaretine gönderdiği telgrafında, Cizre'deki koleranın Asya kolerası olduğu sonucuna vardığını bildirmiştir. Tabip Furado, Asya kolerasına bağlı olarak Nusaybin, Midyat, Mardin, Diyarbakır, Silvan, Urfa, Zaho ve Siirt mevkilerinin muhafazasının gerekliğini de vurgulamıştır. 7 Temmuz 1890 yılında Sıhhiyye Nezaretine gönderdiği diğer bir telgrafında Cizre'de zuhur eden koleranın neden kaynaklandığını açıklamıştır. Furado'ya göre kolera, Cizre'ye iki saat mesafede yirmi gün kadar ikamet eden ve

\footnotetext{
41890 yılında Diyarbakır ve Musul vilayetleri ile Hicaz bölgesini kapsayan ve aralıklarla şiddetli veya hafif seyreden kolera, çok sayıda insanın ölümüne sebep olmuştur. Örneğin 8-10 Temmuz 1890 yılında Erbil'de 38; 11 Temmuz'da 16; 12 Temmuz'da 11 vefat; Mekke-i Mükerreme'de 6 Ağustos 189o'da koleradan 145, 7 Ağustos'ta 122, 8 Ağustos'ta 147, 14 Ağustos'ta 33, 16 Ağustos'ta 29 vefat; Cidde'de ise 6 Ağustos'ta 179, 14 Ağustos'ta 24, 15 Ağustos'ta 20 vefat vuku bulmuştur. Daha geniş bilgi için bkz. BOA, DH. MKT. 1742/1; 1742/23; 1749/68; 1751/89; $1752 / 25$.

51890 yılının Ağustos ayında Dördüncü Ordu Müşirliğinden Makam-ı Seraskeriyyeye gönderilen bir yazıda, Mardin ve Cizre'de görülen küçük çapta bir kolera salgınından söz edilmektedir (Özcoşar, 2006: 795). Burada sözü edilen kolera salgını Ağustos ayına özgü olmayıp, başlangıcı Haziran 1890’a dayanmaktadır. Yine Cizre için belirtildiği üzere 11 Ağustos’a kadar devam eden salgın özellikle Temmuz ve Ağustos başı itibariyle şiddetli seyretmiştir.
} 
bin kadar nüfusu bulunan göçer aşiretinden sirayet etmiştir (BOA, Y. PRK. DH. 3/78; BOA, Y. MTV. 44/16).

Cizre'ye memuren gönderilen Tabip Kolağası Mustafa Efendi'nin 1 Temmuz 1890'dan önce gerçekleştirdiği muayeneler yörede bulaşıcı hastalıklardan eser kalmadığını, yine de kimi şahıslarda hummâ-yi naibe (nöbetli sıtma) görüldüğünü belirlemiştir (BOA, DH. MKT. 1738/16). Ancak 11 Ağustos'a kadar kolera aralıklarla devam edip kayıplara yol açmıştır.

\section{Musap ve Vefat Hadiseleri}

Koleranın zuhur ettiği mahallerdeki en önemli endişe ilgili hastalığa yakalanma, hastalığı bulaştırma ve hastalıktan vefat mevzusu idi. Koleranın zuhurundan defin işlemine kadar olan sürece dair, ilgili makamların merkezi devamlı surette bilgilendirdiği görülmektedir. Diğer bir deyişle merkez ve taşra makamları birbiriyle irtibat sağlayıp salgının etkisini en aza indirmeye çalışmıştır. Bilgi aktarımı merkeze kaymakamlık makamı, kaza mahallinde görev yapan tabipler, Mardin Mutasarrıflığı, Dördüncü Ordu-yi Hümâyûn Müşiriyyeti, Diyarbakır Vilayetince sağlanmaktaydı.

Yetkililerin Cizre'de kolera vukuatına dair yaptıkları incelemeler neticesinde musap ve vefatlarla ilgili bazı verilere ulaşma imkânı elde edilmektedir. Tabip Furado'nun mezkûr telgrafında göçer aşiretinden kaynaklı koleradan dolayı 2 vefat yaşandığı bildirilmektedir. Hatta ilgili aşiretin Hakkâri ve Bitlis dağlarına çıkmalarından Furado'nun inceleme vaktine kadar geçen zaman zarfında söz konusu aşiretten 65 musap olduğu, bunlardan 25'inin yine koleradan vefat ettiği bilgisine yer verilmektedir (BOA, Y. PRK. DH. 3/78).

Tabip Furado 6 Temmuz 1890 tarihli raporunda, 4 Temmuz 1890'da 14 musap 6 vefat; 5 Temmuz'da 10 musap 3 vefat; 6 Temmuz'da 10 musap ve 4 vefat hadisesi yaşandığını belirtmektedir (BOA, Y. PRK. DH. 3/78). Dördüncü Ordu-yi Hümâyûn Müşiri Mehmet Zeki'nin 9 Temmuz 1890 tarihli telgrafnamesi ise 5 Temmuz'da 10 musap 4 vefat olduğuna yer vermektedir (BOA, Y. PRK. ASK. 62/6).Yine Cizre'den Tabip Kolağası Mustafa Efendi'nin 9 Temmuz 1890 tarihli telgrafına binaen Diyarbakır'dan Dahiliyye Nezaretine aktarılan malumatta musap ve vefat vukuatlarına değinilmektedir. Malumata göre Cizre merkez için 7 Temmuz 1890'da 5 musap 4 vefat; 8 Temmuz'da 2 musap 2 vefat yaşanmıştır. Cizre’ye bağlı karyeler için ise “... Civar karyelerde 12 karyeden altısı muaf ve üçü de üç günden beri musabdan ve bunların evvelde 19 vefiyatları olmuş ve diğer üç karyeden birinde kolera şiddetle hükmünü icra ederek vefiyatları 25'e baliğ olarak ve diğer ikisinde hafif surette icra-yı hükm etmekte bulunmuş olduğundan..." bilgisi geçmektedir (BOA, Y. PRK. DH. 3/78).

Diyarbakır Vilayeti, Mabeyn-i Hümâyûn Başkitâbet-i Celilesine ve Tıbbiyye Nezaretine “Nefs-i Cizre'de mah-ı hâlin 25. Günü (7 Temmuz) akşamından beri lehülhamd koleradan musab ve vefiyat olmadığı..." bilgisini aktarmaktadır. Tabip Mustafa Efendi ayrıca hastalığın tedavisi için memurların seri olarak yollanacağını 
belirtmektedir (BOA, DH. MKT. 1740/119; 1749/110). Ancak Mabeyn-i Hümâyûn Başkitâbetine intikal eden bir telgrafta 7-10 Temmuz 1890 tarihlerinde Cizre'de 48 musap ve 56 vefat yaşandığına yer verilmektedir (BOA, DH. MKT. 1742/1).

10 Temmuz'dan 12 Temmuz akşamına kadar Cizre ile Silvan nahiyesinin bazı kurasından 25 musap ve 18 vefat ve diğer iki karyede on günde 19 musap ve 9 vefat vuku bulmuştur (BOA, DH. MKT. 1742/23). 15 Temmuz 1890'da Cizre'de 1 musap ve 1 vefat yaşanmıştır (BOA, DH. MKT. / 1743-77). 16 Temmuz'da Cizre'de herhangi bir musap ve vefat olmadığı Diyarbakır Vilayetince bildirilmektedir ${ }^{6}$ (BOA, DH. MKT. / 1743-118). Ancak 17 Temmuz'da 2 musap, 18 Temmuz'da ise 1 vefat hadisesi gerçekleşmiştir (BOA, DH. MKT. /1744-62). 19 Temmuz'da 3 musap 1 vefat olduğu; 20 Temmuz'da musap ve vefat olmadığı, hatta takip eden üç günde dahi musap ve vefat yaşanmadığı Sıhhiyye ve Tıbbiyye nezaretlerine Diyarbakır Vilayetinden bildirilmiștir (BOA, DH. MKT. 1744/125; 1745-110; BOA, Y. PRK. UM. 17/137). Cizre'ye bağlı 10 karyede ise 8 günden beri hastalık olmadığı, sadece Hazak (İdil) karyesinde musap ve vefat edenler olduğu haber alındığından gerekli tedbirlere girişileceği belirtilmektedir (BOA, DH. MKT. 1746/59). 1 Ağustos 1890'da Cizre'de musap ve vefat hadiseleri hakkında Diyarbakır Vilayetinden Sıhhiyye Nezaretine bilgi verilmiş; ancak musap ve vefat sayıları belirtilmemiștir (BOA, DH. MKT. 1748/15). 6 ve 7 Ağustos'ta 3'er musap ve 2'şer vefat yaşanmış; 8 Ağustos'ta herhangi bir vukuat olmamıştır. 9 Ağustos'ta 2 vefat, 10 Ağustos'ta 3 musap ve 1 vefat, 12 Ağustos'ta 1 musap gerçekleşirken 7, 11-13-14-15-17-18-19-20 ve 24 Ağustos'ta ise vukuat meydana gelmemiştir (BOA, DH. MKT. 1749/68; $1749 / 103 ; 1749 / 110 ; 1750 / 34 ; 1752 / 25 ; 1752 / 30 ; 1753 / 12 ; 1755 / 31 ; 1757 / 81 ; B O A, Y$. PRK. ASK. 63/45; BOA, Y.PRK. DH. 3/83). 31 Ağustos 1890 tarihli belgede Cizre'de

\footnotetext{
${ }^{6} 6$ Temmuz-12 Ağustos 1890 tarihleri arasında koleranın şiddetli seyrettiği ve Cizre'nin bağlı bulunduğu Mardin'de yaşanan musap ve vefat hadiselerine dair şu verilerden söz edilebilir:

Mardin'de 14 Temmuz 1890'da 7 musap olup vefat olmazken, 16 Temmuz'da 5 musap ve 1 vefat hadisesi gerçekleşmiştir. 21-22 Temmuz 189o'da Mardin'de 7 musap ve 4 vefat; 23 Temmuz'da ise 1 musap ve 3 vefat vuku bulmuştur. 1 Ağustos 189o'da Mardin'de 6 musap, 3 vefat; 2 Ağustos'ta musap üç kişinin vefatı; 6 Ağustos'ta 4 musap ve 1 vefat; 7 Ağustos'ta da 5 musap, 3 vefat; 8 Ağustos'ta 4 musap, 2 vefat; 9 Ağustos'ta evvelki musaplardan bir vefat hadisesi yaşanmıștır. 11 Ağustos'ta 1 musap, 12 Ağustos'ta 3 musap olup vefata rastlanmamıştır; ancak Diyarbakır Vilayetinin işarına göre 11 Ağustos için 2 musap olup, biri vefat eylemiş; 12 Ağustos için de Mardin'de musap ve vefat gerçekleșmemiștir. 13 Ağustos'ta 4 musap olup ikisi vefat eylemiştir. 14 Ağustos'ta 3 musap 1 vefat; 15 Ağustos'ta ise 2 musap olup biri vefat eylemiştir. 17-24 Ağustos tarihlerinde de Mardin'de herhangi bir vukuat yaşanmamıştır. Ancak hastalığa tutulan bir neferin otuz altı saat zarfında vefat eylediği bildirilmektedir. 25 Ağustos'ta 2 musap olup biri vefat etmiştir. Yine 27-29 Ağustos tarihlerinde de musap ve vefat olmamıștır. Diğer taraftan Mardin ile Cizre arasındaki Nusaybin kasabasıyla bağlı yerlerde 12 Temmuz-2 Ağustos 1890 tarihlerinde 191 musap ve 37 vefatın yaşanmış olması koleranın yol açtığı tahribatı göstermesi bakımından önem taşımaktadır. Yerel makamların işarına atfen Dördüncü Ordu-yi Hümâyûn Müşiriyyetinin aktarımında ise 191 musap bilgisi aynı iken 137 vefat geçmektedir. Nitekim ilk belgede, Nusaybin kazası dâhilinde 100 'ü aşkın telefettan bahsedilmesi 137 rakamını daha makul kılmaktadır. Nusaybin kaymakamının hastalık hususunda fevkâlade ağır davranmak suretiyle ihmali, Nusaybin ve civarındaki hastalık ile kayıpların oldukça fazla seyretmesine yol açmıştır. Üstelik hastalığın zuhurundan ilgili makamlara bilgi vermemiștir. Dolayısıyla Nusaybin'e ehil ve muktedir bir kaymakamın tayini talep edilmiştir (BOA, DH. MKT. 1759/107; 1743/118; 1745/110; 1746/59; 1747/89; 1748/15; 1749/68; 1749/103; 1749/110; 1752/25; 1755/3; 1755/31; 1756/67; BOA, Y. PRK. DH. 3/83; BOA, Y. PRK. ASK. 63/45). Mardin'de kolera illetinin zuhur edilişi kabul edilen 15 Temmuz 1890'dan başlamak üzere 7 Ağustos 1890 yllına kadar 99 musap ve 44 vefat vuku bulduğundan söz edilmektedir (BOA, Y. PRK. ASK. 63/45).

7 Diyarbakır Vilayetinin işarına göre ise 12 Ağustos'ta Cizre'de hem musap hem de vefat gerçekleşmemiştir (BOA, DH. MKT. /1755-31).
} 
11'den başlamak üzere 30 Ağustos tarihine kadar musap ve vefat olmadığına yer verilmektedir (BOA, DH. MKT. 1756/67). 2 Eylül'de Cizre'de bir vukuat olmadığı, hatta Cizre ve havalisinde hastalıktan eser kalmadığı Diyarbakır Vilayetinden Sıhhiyye Nezaretine bildirilmiştir (BOA, DH. MKT. 1757/139;1758/10).

Tüm bu anlatımlardan musap ve vefatlara dair şöyle bir tablo oluşturmak mümkündür:

Tablo 1: 1890 tarihli Kolera Salgınından Dolayı Cizre'de Yaşanan Musap ve Vefat Sayıları

\begin{tabular}{|c|c|c|}
\hline Tarih & Musap & Vefat \\
\hline 1-3 Temmuz & Net sayı tespit edilemedi & 2 \\
\hline 4 Temmuz & 14 & 6 \\
\hline 5 Temmuz & 10 & 3 ya da 4 \\
\hline 6 Temmuz & 10 & 4 \\
\hline 7 Temmuz & 5 & 4 \\
\hline 8 Temmuz & 2 & 2 \\
\hline 7-10 Temmuz & 56 & 48 \\
\hline 10-15 Temmuz & Net sayı tespit edilemedi & Net sayı tespit edilemedi \\
\hline 15 Temmuz & 1 & 1 \\
\hline 16 Temmuz & Vaka yok & Vaka yok \\
\hline 17 Temmuz & 2 & Vaka yok \\
\hline 18 Temmuz & Vaka yok & 1 \\
\hline 19 Temmuz & 3 & 1 \\
\hline $\begin{array}{c}20 \text { Temmuz }-5 \\
\text { Ağustos }\end{array}$ & Vaka tespit edilemedi & Vaka tespit edilemedi \\
\hline 6 Ağustos & 3 & 2 \\
\hline 7 Ağustos & 3 & 2 \\
\hline
\end{tabular}




\begin{tabular}{|c|c|c|}
\hline 8 Ağustos & Vaka yok & Vaka yok \\
\hline 9 Ağustos & Vaka yok & 1 \\
\hline 10 Ağustos & 3 & Vaka yok \\
\hline 11 Ağustos & Vaka yok & Vaka yok \\
\hline 12 Ağustos & 1 ya da vaka yok & Vaka yok \\
\hline $13-30$ Ağustos & Vaka yok & 79 ya da 80 vefat vakası \\
\hline Toplam & 112 ya da 113 musap vakası &
\end{tabular}

Tablodaki 112-113 musap ile 79-80 vefat verileri Cizre şehir merkezini kapsamaktadır. Tabloya, Cizre'ye bağlı karyelerde Tabip Furado'nun 9 Temmuz tarihli telgrafında belirttiği 25 vefat eklenmemiştir. 10 Temmuz'dan 12 Temmuz akşamına kadar Cizre ile Silvan nahiyesinde meydana geldiği belirtilen 34 musap ve 27 vefat vakası da dâhil edilmemiştir. Çünkü ne kadarının Cizre ne kadarının Silvan'ı kapsadığı belli değildir. Diğer taraftan göçer aşiretindeki 65 musap ve 25 vefat, Cizre'deki ikametleri sırasında gerçekleştiğinden tüm bunlarla birlikte tahmini bir yaklaşımla 1890 yılı kolera hastalığının Cizre ve çevresinde 180'in üzerinde musap ve 130'un üzerinde de vefat vakasına yol açtığı söylenebilir.

Cizre'nin merkez nüfusu müslim ve gayrimüslim toplamı 1876 yılında 1441'dir (Diyarbakır Salnameleri, Cilt 2, s. 337). Sur içi bir yerleşim gösteren Cizre'nin merkez nüfusunun, salgının yaşandığı 1890 yılına kadar çok değişmeyeceği dikkate alınırsa salgın nedeniyle merkez bazında ortalama \%5 civarında bir nüfus kaybı yaşandığı söylenebilir.

Cizre'deki kolera salgının yol açtığı vefat vakaları 1890'lı yıllarda Osmanlı Devleti'ndeki diğer kimi yerleşimlerle kıyaslanabilir. 1892'de Erzincan şehir merkezinde 294 kişi kolera hastalığına yakalanmış ve bunlardan 130'u vefat etmiştir Gül, 2009: 252). 1893 kolerası Bağdat şehir merkezinde 250 kişinin vefatına yol açmıştır. Trabzon'da 1893 yılı Ağustos ayı ortalarında başlayıp 1894 yılının ilk günlerine kadar devam eden salgında 419 kişi hastalığa yakalanmış olup bunlardan 270'i vefat etmiştir. İzmir'de 1893 yılının Temmuz ortalarından Kasım başına kadar hastalığa yakalanan 547 kişiden 405'i vefat etmiştir. Edirne'de 1893 yılı Aralık ayı sonlarından 1894 Ocak ortalarına kadar koleradan 45 vefat vuku bulmuştur. 1894 yılının 14 Haziran - 27 Ağustos tarihlerini kapsayan süreçte Malatya'da yaşanan şiddetli bir kolera salgını, bir buçuk aylık süre zarfında hastalığa yakalanan 709 kişiden 312'sinin vefatı ile sonuçlanmıştır. Antalya'da 1894 yılındaki salgından 353 kişi etkilenmiş ve 182 kişi vefat etmiştir (Ayar, 2007: 74-139). Diyarbakır şehir merkezinde 11 Kasım 1894'ten 7 Aralık 1894 yılına kadar yaşanan kolera salgınına yakalanan 123 kişiden 70’i vefat etmiştir (Bozan, 2015: 
224). Tarsus'ta 1895 Mayıs ayının ilk haftasında ortaya çıkıp şiddetli bir şekilde seyreden ve bir buçuk aydan fazla devam eden salgında vaka sayısı 1225, vefat ise 845’i bulmuştur (Uğuz, 2012: 443). Verilen örneklerden Cizre'deki vefat vakalarının Erzincan'da yaşanan vefat vakalarıla aynı olduğunu, Edirne ve Diyarbakır'dan ise fazla seyrettiğini ve diğer yerleşim yerlerindeki vefat vakalarının çok altında kaldığını söylemek mümkündür. Diğer taraftan hastalığın görüldüğü yerlerde etki süresi koleranın ortaya çıktığı andan tamamen sonlanmasına kadar ortalama 3-4 aya tekabül etmekteydi. Salgının şiddetli hali de Cizre'de olduğu gibi alınan tedbirlerle değişmekle birlikte 1-1.5 ayı bulabilmekteydi.

\section{Alınan Tedbirler ve Karantina Uygulaması}

Kolera salgınının zuhur ettiği mahallerde merkez tarafından bașvurulan ilk uygulamalardan biri yapılan tabip atamalarıdır. Koleranın şiddetli görüldüğü dönemlerde askeri-beledi tabip ve eczacılar büyük gayretler gösterip hasta olan kişileri tedavi etmişlerdir. Yaptıkları bu işlerden dolayı kendilerine maaş ve harcırah ödenmesi yoluna gidilmiştir (Gül, 2009: 253). Aynı uygulama Cizre için de geçerlidir.

Tabip Furado Cizre'ye vardıktan ve kolera vakasını raporla tasdik ettikten sonra ilgili makamlara hangi mevkilerde muhafaza kordonlarının teşkili lazım geleceğini detaylı bir şekilde bildirmiştir. Tabip Furado'nun raporu dikkate alınarak ilgili makamlara Musul, Bitlis, Halep, Urfa cihetlerinde; Diyarbakır Vilayeti dâhilinde bulunan Derik, Beşiri, Silvan, Yenişehir ve Diyarbakır'a iki saat mesafede olan Karaköprü mevkilerinde ve Mardin Sancağı'nın gerek görülen noktalarında birer muhafaza kordonunun ve Cizre ile Nusaybin arasında dahi bir karantina kordonunun hemen teşkil edilmesi için telgraflar çekilmiştir. Ayrıca Diyarbakır Vilayeti dâhilinde bulunan mezkûr mevkilerin muhafazasının sağlanması için piyade-i asakir-i şahaneden birer onbaşı takımı gönderilmiştir (BOA, Y. PRK. TKM. 18/15).

Diyarbakır Vilayet gazetesinde yayınlanan bir makalede koleranın genişleme ve yayılma göstermesine önemli bir sebep olarak nizamdan yoksunluk gösterilmektedir (BOA, Y. PRK. TKM. 18/15). Cizre kazasındaki koleranın yayılmak suretiyle bulaşmasını engellemeye dönük olarak Diyarbakır Vilayetince birtakım tedbirlere başvurulmuştur. Her türlü sıhhi korunma tedbiri alınmaya çalışılırken ahalinin desteği önemsenmiştir. Bu kapsamda belediye dairesince temizlik işlerinin yol, sokak ve hanelere ait kısmı ahaliye yaptırılmıştır. Diğer taraftan ahalinin iktidarı haricinde bulunan ve doğrudan belediye dairesinin görev alanında bulunan müzahrefâtın da (pislikler, süprüntüler) temizlenmesi ve imhası gerekmiştir. Ancak müzahrefât için temmuz ve ağustos aylarında dairece sarfına ihtiyaç görülen 35000 kuruşun karşılanması talep edilmiştir (BOA, DH. MKT. 1740/55). Talebe acilen cevap verilmesi gerektiği Sıhhiyye Nezaretine bildirilmiştir (BOA, DH. MKT. 1740/127). 
Cizre'de karantina uygulamasına geçilmek istendiği ve bu yönde teşebbüste bulunulduğu anlaşılmaktadır. Karantina için gerekli tıbbi ilaç ve malzemelerin tedarik edilmesi, Cizre'deki askeri memurlar vasıtasıyla Diyarbakır Vilayetine bildirilmişse de Sıhhiyye Nezaretine intikal eden mevzu hakkında malzeme tedarikinin ve masrafların karşılanmasının mahallince sağlanması uygun görülmüştür (BOA, DH. MKT. 1725/34). Diğer taraftan Vilayet gazetesince vilayet dâhilindeki kasaba ve karyelerde tahaffuz tedbirlerinin icrasına ehemmiyet verilmesine dikkat çekilmiştir. Koleranın derecesi ve buna bağlı olarak alınacak sıhhi tedbirler ve korunma tedbirleri için Cizre'de bulunan Tabip Furado ile Mustafa Efendi gerekli mahallere kordon konulmasını, Cizre'nin tabi olduğu Mardin Mutasarrıflığına yazmışlardır (BOA, Y. PRK. TKM. 18/15; BOA, DH. MKT. 1740/23). Herhangi bir kişinin yakalandığı hastalığın kolera olup olmadığı tabipler vasıtasıyla teşhis edilmeye çalışılmıştır. Teşhis konuluncaya kadar hastalık mahali tedbir amaçlı kordon altına alınmakta, tahaffuz ve tanzifat kuralları devreye sokulmaktaydı (BOA, DH. MKT. 1757/43).

Tabip Furado'nun belirlediği Asya kolerasına karşı, Cizre ahalisine sıhhatlerini muhafaza ve hastalığın defi için tavsiyelerde bulunulmuştur. Tabip Furado ayrıca Cizre ve çevresi ile vilayetin muhafazası hususunda Sıhhiyye Nezaretinden Diyarbakır Valisi Hasan Bey'e sıhhi emirler buyurulmasını talep etmiş ve Cizre'de eczacı ile eczanın olmadığına dikkat çekmiştir (BOA, Y. PRK. $\mathrm{DH}$. 3/78). Kolerayla mücadelede kimi zaman yollanan tabiplerin de hastalanmaları tedbirleri aksatabilmekteydi (BOA, DH. KKT. 1749/68).

Cizre'de zuhur eden hastalık civardaki beş karyeye de sirayet ettiğinden karantina kordonlarının Cizre ile Nusaybin arasında teşkiline ihtiyaç duyulmuştur (BOA, DH. MKT. 1740/85). Tabip Furado, hastalığın sirayet alanının genişlemesine bağlı olarak Diyarbakır-Midyat cihetini kordona alma yoluna gitmiştir (BOA, Y. PRK. DH. 3/78). Mardin dâhilindeki kordonlar için civar mevkilerden 3 tabip ile 2 eczacının süratle gönderilmesi ve koleraya yakalanmalarından dolayı Cizre civarında karantinaya konulan bir bölük süvarinin illetten salim oldukları halde münâsafaten Nusaybin kordonuyla ve Diyarbakır'da bulundurulması zımnında cihet-i askeriyeye müracaat olunmuştur (BOA, DH. MKT. 1742/23). Mardin dâhilindeki kordonlar için Dördüncü Ordu-yi Hümâyûn'dan ihtiyaca binaen talep edilen tabip ve eczacıların gönderilmesinin gecikmesi üzerine ilgili makamlara gereğinin acilen yapılması talimatı verilmiştir (BOA, DH. MKT. 1743/77). En nihayetinde Mardin, Cizre, Nusaybin ve Hamidiye'de karantina uygulamasına geçilmiştir (BOA, DH. MKT. 1759/107). Cizre için istenen tabip sayısı iki ve eczacı sayısı ise birdir. Bu hususta yine Dördüncü Ordu-yi Hümâyûn Müşiriyyetine emir verilmiştir. Yedinci Fırka Kumandanlığının gerekli ecza ve eczacıyı gönderme sorumluluğunu üstlendiği görülmektedir (BOA, Y. PRK. ASK. 62/6; BOA, DH. MKT. 1744/74).

Kordonların teşekkülüne karşın önemli bir sıkıntı, firar edebilecek kişilerdi. Hem firarlar edebileceklerden hem de firarilerden kaynaklı hastalığın sirayetinin 
önüne geçmek için yeteri kadar asker, polis ve jandarma bulundurulması suretiyle muhafazanın sağlanması cihetine gidilmiştir (BOA, DH. MKT. 1743/77). Belirtildiği üzere koleranın sirayetinin sebeplerinden biri Cizre ve çevresinden Hakkâri ve Bitlis dağlarına giden göçer aşiretlerdir. Göçer aşiretlerin serbest bir şekilde gezip dolaşmalarının hastalığı süratle yayacağı endişesinden dolayı söz konusu aşiretlerin dahi uygun mahallerde kordon altına alınarak içlerinde hastalıktan eser kalmayıncaya kadar etraf ile temaslarının kesinlikle önlenmesi cihetine gidilmesinin zorunlu olduğuna dikkat çekilmiştir. Bu şekilde bir bakıma göçer aşiretlerin kontrol altında tutulmasının önemi vurgulanmıştır (BOA, DH. MKT. 1750/86).

Hastalık atlatıldığı zaman mahallerde teşkil olunan kordonların kaldırılması cihetine gidilirdi (BOA, DH. MKT. 1756/67). 17 Eylül 1890 tarihli bir belgede, 11 Ağustos 1890'dan itibaren herhangi bir vukuatın yaşanmamasına binaen tabipler tarafından verilen rapor doğrultusunda karantina uygulamasına son verilmesi talep edilmiştir (BOA, DH. MKT. 1762/45). Diyarbakır Vilayetinin 18 Eylül 1890; Dördüncü Ordu-yi Hümâyûn Müşiriyyetinin ise 11 Ekim 1890 tarihli telgrafnameleri de Cizre'de koleranın artık son bulduğunu bildirmektedir (BOA, DH. MKT. 1762/71; BOA, Y. PRK. ASK. 65/104).

Kolera hastalığının def edilmesinden yaklaşık bir yıl sonra, hastalığın yeniden zuhuru ihtimaline karşı tedbir mahiyetinde, Meclis-i Umur-i Sıhhiyyenin bildirimi ve Şura-yı Devlet ile Meclis-i Meşveretin onayıyla Cizre'nin de dâhil olduğu lüzumlu mahallere birer tabip tayin edilmesi yoluna gidilmiştir. Tayin edilen tabiplerin maaşlarının ödenmesinde belediyelerin varidatı yeterli ise belediyelerce, değilse hazineden karşılanmasının uygun olacağı kabul edilmiştir. Cizre Belediyesinin varidatının tabip maaşını karşılamaya yeterli olduğu belirtilmiștir (BOA, DH. MKT. 1849/114).

1890 yılı kolera salgınından sonra hafif seyreden kolera vakaları yaşanmıştır. 1895 ve 1910 yıllarında Cizre'de kolera yeniden zuhur etmişse de bunun etkisi, yol açtığı musap ve vefatlara dair malumat bulunmadığından dolayı bilinememektedir. 1895'te hastalığın civar mahallerde de zuhur etme tehlikesine karşı 1000 kuruş maaş verilmek üzere bir beledi tabibinin süratle tayini Diyarbakır Vilayetinden 12 Ağustos 1895 yılındaki telgrafnamede talep edilmiştir (BOA, DH. MKT. 415/19). 1910 yılı sonlarındaki kolera vakasından dolayı hastalığın sirayetini önlemeye dönük kordon tertibine gidilmiştir. Kordonların muhafazası için 20, 30 nefer nizamiye süvarisinin gönderilmesi lüzumu Harbiyye Nezaretine yazılmıştır. Ancak koleranın etkisini yitirmek üzere bulunması, Nusaybin ve Mardin'de hastalığa yakalananların olmaması ve Cizre'nin Urfa'ya uzaklığı da dikkate alınarak Urfa nezdinde fevkâlade tedbirlere lüzum bulunmadığı hem Urfa Mutasarrıflığı hem de Beşinci Ordu Kumandanlığından bildirilmiştir (BOA, DH. iD. 50/39).

1890 yılı öncesi ve 1890 yılından itibaren yaşanan kolera salgınlarında Cizre ve diğer muhtelif yerlerde benzer ve farklı tedbirlere başvurulduğu 
görülmektedir. Cizre'de olduğu gibi tüm mahallerde karantina uygulaması, kordon altına alma, tabip tayini öncelikli tedbir olmuştur. Diğer tedbirler ise imkânlara ve tercihe bağlı olarak değişebilmiştir. Örneğin 1890 yılı İzmir ya da 1894 yılı Antalya kolera salgınlarında karantinalara konulmak üzere etüv ve pülverizatörlerin İstanbul'dan temin edilebilmesi imkân dâhilinde olmuştur ${ }^{8}$ (Ayar, 2007: 95; Ak, 2011: 262). 1893 yılının Haziran ayında Malatya'da başlayan koleraya karşı halkın evlerine kapanıp dışarı çıkmaması kendilerinin tercihi olmuştur (Yıldız, 2014: 42). Yetişmiş sağlık personeli sıkıntısı ise tüm Osmanlı yerleşmelerinde mevcuttu (Ayar, 2007:95).

\section{Sonuç}

Salgın hastalıklar, zuhur ettiği yerin sosyo-ekonomik yapısı üzerindeki tesiriyle hayatın olağan akışını değiştirebilmiştir. Cizre de tarihin her döneminde özellikle de XIX. yüzyılda birçok kez salgın hastalıklara maruz kalmıştır. Mezkûr yüzyılda etkisini en çok hissettiren salgın hastalık kolera olmuştur. Birçok defa koleraya maruz kalan Cizre'de özellikle 1890 yılındaki kolera salgını, musap ve vefat bakımından yörede iz bırakmıştır. Koleranın yayılmasında ve hatırı sayılır ölüm vakalarına yol açmasında halkın bilinç düzeyinin düşüklüğü, sıhhi tedbirlerin ve sağlık hizmetlerinin yetersizliği, hijyen imkânlarından yoksunluk, Cizre'nin coğrafi yapısı ile birlikte işlek yollar üzerinde bulunması gibi sebepler etkili olmuştur.

Cizre'de halk, salgın esnasında tedbir olabilecek imkânlara sahip değildi. Bunun bilincindeki Osmanlı merkezi ve mülki makamları kolera tehdidi karşısında tepkisiz kalmamış, ilgili birimler nezdinde kolera tehdidinin önlenebilmesi girişimleri başlatılmıştır. Cizre'deki kolera salgınında, merkez ve civar yerlerde özellikle bağlı bulunulan Mardin Sancağına bağlantıyı sağlayan Nusaybin ve Midyat hatlarında- karantina ve kordon altına alma uygulamalarına başvurulmuştur. Karantina ve kordon uygulamaları ile halkın salgından daha fazla etkilenmemesi sağlanmıştır. Ayrıca yeterli olmasa da tayin edilen tabiplerin girişimleri, hem hastalığın sirayetinin büyük ölçüde önlenmesinde hem de hastalığın def edilmesinde rol oynamıştır.

1890 kolera salgını Cizre'nin nüfusunu, sosyal yapısını ve ekonomisini olumsuz yönde etkilemiştir. Özellikle hayvancılıkla uğraşan ve yaylalara çıkan göçer aşiretlerden yayılan koleradan dolayı bunların kontrol altında tutulmak istenmesi, kendileri ve ekonomik uğraşıları açısından önemli bir sıkıntı oluşturmuştur. Ayrıca üretimin sekteye uğraması ahalinin de ihtiyaçlarını karşılayamaması sonucunu doğurmuştur. Dicle Nehri kenarında yer alan Cizre’ye giriş çıkışların karantina ve kordonlardan dolayı kontrol altında tutulmasının

\footnotetext{
8 Pülverizatör: Günümüzde daha çok tarımsal faaliyetlerde kullanılan ve sıvı ilaçları püskürtmeye yarayan aletin adıdır. Pülverizatör, mikropların dezenfekte edilmesi amacıyla ilaçlama yapmak için salgın dönemlerinde kullanılan en önemli araçlardandır. Bkz. Uğuz, s. 442.
} 
ulaşımı da aksattığı söylenebilir ${ }^{9}$. Yine koleranın yol açtığı kayıplar sosyal dokuyu etkilediği gibi ahalinin psikolojik yönden çöküntü yaşamalarına sebebiyet vermiştir.

\section{Kaynakça}

\section{Başbakanlık Osmanlı Arşivi Belgeleri (BOA)}

A. AMD. 20/50.

DH. ID. 50/39;

DH. MKT. 415/19; 1678/50; 1725/34; 1737/62; 1738/16; 1740/23; 1740/55; 1740/85; $1740 / 119 ; 1740 / 127 ; 1742 / 1 ; 1742 / 23 ; 1743 / 77 ; 1743 / 118 ; 1744 / 62 ; 1744 / 74 ;$ $1744 / 125 ; 1745 / 110 ; 1746 / 59 ; 1747 / 89 ; 1748 / 15 ; 1749 / 68 ; 1749 / 103 ; 1749 / 110 ;$ $1750 / 34 ; 1750 / 86 ; 1751 / 89 ; 1752 / 25 ; 1752 / 30 ; 1753 / 12 ; 1755 / 31 ; 1756 / 67 ; 1757 / 43$; $1757 / 81 ; 1757 / 139 ; 1758 / 10 ; 1759 / 107 ; 1762 / 45 ; 1762 / 71 ; 1849 / 114$.

MKT. MHM. 359/26/; 346/83; 358/35.

Y. HUS. 236//60.

Y. MTV. 44/16.

Y. PRK. ASK. 62/6; 63/45; 65/104.

Y. PRK. DH. 3/78; 3/83.

Y. PRK. TKM. $18 / 15$.

Y. PRK. UM. $17 / 137$.

Telif ve Inceleme Eserler

Ak, M. (2011). 19. Yüzyılda Antalya'da Kolera Salgını. Uluslararası Sosyal Araştırmalar, 4 (17), 254-268.

Akyıldız, A. (1993). Tanzimat Dönemi Osmanlı Merkez Teşkilatında Reform (18361856). İstanbul: Eren.

Arslan, E. (2015). Trabzon Vilayeti'nde Kolera (1892-1895). Yayımlanmamış Yüksek Lisans Tezi, Karadeniz Teknik Üniversitesi, Trabzon.

Asan, H. (2018). Bitlis Vilayetinde Yaşanan Kıtlık Hadiseleri (1887-1894). Turkish Studies History, 13 (8), 1-17.

Ayar, M. (2007). Osmanlı Devleti'nde Kolera İstanbul Örneği (1892-1895). Kitabevi Yayınları, istanbul.

Bozan, O. (2015). Diyarbakır Vilayeti'nde 1894-1895 Kolera Salgını ve Etkileri. Türk Dünyası Araştırmaları, 218, 219-240.

Dağlar, O. (2007). Denizli ve Çevresinde Kolera Salgını ve Salgınla Mücadele. Denizli 6-7-8 2006 içinde (s. 368-374), Denizli: Özkan.

\footnotetext{
9 Cizre önünden geçen Dicle Nehri üzerinde, 1890 yılı başları itibariyle harap olmuş bir kârgir köprü ve kullanıma açık ahşap bir köprü mevcuttur. Ahşap köprünün resm-i müruru (geçiş vergisi) Cizre Belediyesine ait olup, her sene yüz bin kuruş kadar bedelle taliplisine ihale edilir. Etrafında bulunan aşâir ve urbân yaylaya gidecekleri zaman koyunlarını mezkûr köprüden geçirirler. Bkz. Diyarbakır Salnameleri, Cilt 4, s. 65). Salgın zamanında bu işlemler aksadığından ekonomik kayıplara ve şehre giriş çıkışlar sıkı kontrole tabi tutulduğundan halkın zorluk yaşamalarına yol açmıştır.
} 
Develioğlu, F. (2008). Osmanlıca-Türkçe Ansiklopedik Lûgat, (25. Baskı). Ankara: Aydın.

Diyarbakır Salnameleri Cilt 2, (A. Z. İzgöer, Haz.), Diyarbakır Büyükşehir Belediyesi Yayınları, İstanbul 1999.

Diyarbakır Salnameleri Cilt 4, (A. Z. İzgöer, Haz.), Diyarbakır Büyükşehir Belediyesi Yayınları, i̇stanbul 1999.

Dolapönü, H. (1972). Tarih'te Mardin. İstanbul: Hilal.

Gandur, M. Y. (1990). Târîhu Cezireti İbn Ömer (M. 815-1515/H. 200-961). Beyrut: Dârü'l-Fikri'l-Lübnani.

Gül, A. (2009). XIX. Yüzyılda Erzincan Kazasında Salgın Hastalıklar (Kolera, Frengi, Çiçek ve Kızamık). A.Ü. Türkiyat Araştırmaları Enstitüsü, 41, 239-270.

Kılıç, O. (2004). Genel Hatlarıyla Dünyada ve Osmanlı Devleti'nde Salgın Hastalıklar. Elazığ: Fırat Üniversitesi.

Makrîzî, (1971). Kitâbü's-sülûk li-ma'rifeti düveli'l-mülûk. Kahire.

Özcoşar, í. (2006). 19. Yüzyılda Mardin Nüfusu. Mardin 26-27-28 Mayıs 2006 içinde (s. 793-802). İstanbul: İmak Ofset.

Pakalın, M. Z. (1993). Osmanlı Tarih Deyimleri ve Terimleri Sözlüğü. C. 3, Milli Eğitim Basımevi, İstanbul.

Panzac, D. (1997). Osmanlı İmparatorluğu'nda Veba (1700-1850). İstanbul: Tarih Vakfı Yurt.

Shiel, J. (1838). Notes on a Journey From Tabriz, Through Kurdistan, Via Van, Bitlis, Se'ert and Erbil, Suleimaniyeh, in July and August, 1836, The Journal of the Royal Geographical Society of London, 8, 54-101.

Sarıyıldız, G. (1996). Hicaz Karantina Teşkilatı (1865-1914). Ankara: Türk Tarih Kurumu.

Sarıyıldız, G. (2001). XIX. Yüzyılda Osmanlı İmparatorluğu’nda Kolera Salgını. İstanbul 22-23 Mayıs 2000 içinde (s. 309-319). İstanbul: Globus Dünya.

Tüzün, M. (2014). Cizre Tarihi. İstanbul: Nûbihar.

Uğuz, S. (2012). 1895 Tarsus Kolera Salgını. History Studies, 4 (Özel Sayı), 437448.

Yıldıım, N. (2006). Osmanlı Coğrafyasında Karantina Uygulamalarına İsyanlar Karantina İstemezük. Toplumsal Tarih, 150, 18-27.

Yıldız, F. (2014). 19. Yüzyılda Anadolu'da Salgın Hastalıklar (Veba, Kolera, Çiçek, Sıtma) Ve Salgın Hastalıklarla Mücadele Yöntemleri. Yayımlanmamış Yüksek Lisans Tezi, Pamukkale Üniversitesi, Kütahya.

Yılmaz, Ö. (2017). 1847-1848 Kolera Salgını ve Osmanlı Devleti'ne Etkileri. Avrasya incelemeleri-Journal of Eurasian Inquires, VI (I), 23-55. 